\title{
Effects of postsocialist deindustrialization in Central and Eastern Europe: Results of an industrial site survey and GIS mapping in Bucharest City, Romania
}

\author{
Gabriel Simion* \\ University of Bucharest, Romania
}

This paper examines effects of postsocialist deindustrialization through a case study from Bucharest City, Romania. The paper use scientific papers and real estate company reports to analyse the postsocialist transformation of former industrial plants in Central and Eastern European countries and an industrial site survey and GIS mapping for Bucharest. The results show a common pattern for the postsocialist countries, with effects on diminishing the role of industry in the total economy, the tendency to convert the plants to residential and commercial use. In several cases the plants are fragmented in small production units or abandoned awaiting for a new purpose. Socio-economic transformation suggests a transition to service sector for the labour market. The paper concludes that transformation of postsocialist plants might require attention from owners and public administration, especially for the buildings with the historical and architectural meaning. .

Key Words: deindustrialization, postsocialist transformation, GIS mapping, Bucharest City.

Article Info: Received: April 3, 2015; Revised: March 25, 2016; Accepted: May 8, 2016; Online:June 5, 2016.

\section{Introduction}

Iindustry has been the main sector of the socialist economy, but there are few papers in geographical literature with the aims of analyse the situation of postsocialist plants (Kiss, 2007; Lintz, Müller \& Schmude, 2007). The trajectories of the former socialist plants are studied in conjunction with other topics such as changing urban spatial structure or urban sprawl (Nuissl \& Rink, 2005; Kotus, 2006; Sýkora, 1999; Staddon \& Mollov, 2000; Marcinczak \& Sagan 2011;

\footnotetext{
* Corresponding author

Address: University of Bucharest, Faculty of Geography, 1 Nicolae Balcescu Avenue, 010041, Bucharest, Romania.

Phone: +40213153074 | Email: gabriel.simion@geo.unibuc.ro
} 
Polanska, 2008; Hirt 2008). After 1948, manufacturing has been the main supported economic activity by the new socialist states of Central and Eastern Europe (CEE). The socialist governments have started a 'forced' industrialisation process (Barta el al., 2006). It represented the target of countries development strategies and the proud for the new 'socialist city' (Nuissl \& Rink, 2005). The proportion ratio of the industrial workers increased spectacular in the case of Budapest from 21.6\% in 1940 to 34.0 in 1960 (Barta el al., 2006).

There were different actions in the industrialisation process of the new socialist countries. In eastern Germany, policies of urban and economic planning and development were oriented to support the industrialization of formerly rural zone, rather than the modernization of old industrialized regions (Nuissl \& Rink, 2005). In the cases of Sofia and Belgrade industrial plants were built-up first at the urban edge (e.g., the Tito Shipyard in Belgrade and the chemical giant Kremikovtsi in Sofia), but also in certain inner urban locations (e.g., warehousing and engine plants in central Belgrade and textiles in central Sofia) (Hirt, 2008). In Hungary decision-makers concentrate the new plants in the existing industrial area or cities. Gigantic industrial investments were started in that time.

Closing the factories in the former rural and peripheral areas, ironically named by Grabher (1997) 'cathedrals in the desert', re-confirmed the peripherally position of these regions (Lintz, Müller \& Schmude, 2007). Manufacturing attracted a large part of local labour, and it has been the main cause for deruralisation, employers been transported daily as commuters from the periphery villages, or were built workers' hostels for people living farther away from the industrialised cities (Barta el al., 2006). In other cities as Moscow and Bucharest, due to the administrative restrictions for those who did not have the right to reside there, the urban regions were pure 'dormitory towns' from which people migrate daily to work. During the lately socialism time there were erected industrial zones (Rudolph \& Brade, 2005).

Deindustrialization is the process of closing factories and losing jobs, and transformation in term of spatial and functional use of the former plants. The Western deindustrialization was on-going gradually during 1970s and 1980s, with the exception of Great Britain with a rapid industry restructuring. The first and most influential work on Western deindustrialization was Bluestone and Harrison's book 'The Deindustrialization of America', published in 1982. Authors argued that in the capitalist economy, deindustrialization was a deliberate corporate strategy to move capital out of manufacturing and reinvest it in more profitable (and speculative) activities such as financial services. Contemporary with Western deindustrialization, in the socialist countries deindustrialization was rejected by the governments which continued to support large manufacturing plants (Noody, 2012).

The causes of deindustrialization in Central and Eastern European socialist countries are different compared with those from capitalist system. Disband of the former Council for Mutual Economic Assistance (COMECON), in 1991, put the manufacturing in a new economic reality. The result was the losing of the markets space of COMECON, where most prevailed was the quantity instead of quality (Nuissl \& Rink, 2005). It is argued that not only the industry but entire socialist economic system had to be overhauled (Kiss, 2007), and economic 
restructuring had been artificially delayed due to attention gave by government to industrial growth (Stanilov, 2007)

The first phase was a diminishing of the manufacturing, characterised by the reducing of employers and productions, and the second phase was the closing of factories and large industrial area appeared as brownfields (Chelcea, 2008). The open market affected formerly high-status sectors, such as microelectronics in the former German Democratic Republic, or aircraft construction in Ukraine (Lintz, Müller \& Schmude, 2007). The problems associated with deindustrialization in the postsocialist CEE countries are most prominent in the single-industry regions, dominated by mining or steel production. In order to help these regions, in Bulgaria, Romania, Czech Republic, eastern Germany, states designated area for development eligible for national assistance. A rapid tertiarization and a very dynamic development of the small business sector were started. Lentz (2002) indicate that the post-socialist deindustrialization and the tertiarization have their origins form socialist period, and the significant example of Budapest support this theory. Here, the decreasing of industrial earners begun already from 1965 (612,000) to 1988 (318,000) (Barta et al. 2006). In the Sofia case, employment in the tertiary sector increased from $53 \%$ to $74 \%$ in Sofia (Hirt, 2008).

One of the most dramatic declining of the number of employers in the industrial sector was registered in the eastern Germany, where between 1989 and 1995, around 70-90\% of industrial jobs gone, and the official unemployment rate hit 20\% in 2004 (Nuissl \& Rink, 2005). In the case of Leipzig the number of industrial jobs shrink from more than 100,000 in 1989 to less than 10,000 in 2005 (Nuissl\&Rink, 2005: 127). from $39 \%$ in 1989 to $32 \%$ in 2005 in Belgrade, and from $45 \%$ to $23 \%$ in Sofia (Hirt, 2008). Another example is Fryasino, a former scientific town in the north-west of the Moscow urban region, were a registered 28,500 people employed in four large research and production complexes, producing electronic, radio and laser technologies at the early ' 90 s had dropped to about 5,900 in 1999. In this case, the workers have the options to daily commute to Moscow and other cities with a more development labour market offers. Vanishing of industrial jobs was compensated by the extremely growing banking sector, the spread of companies in the finance and services industries. The investments in the financially sector reshape not only the structure of active population but it has effects on the spatial structure of urban regions, as in the Moscow case (Rudolph \& Brade, 2005).

This paper analyses the effects of postsocialist deindustrialization in Bucharest, Romania. The analyse targets three main research questions: First, What is the present use of the former socialist plants in the main cities of Central and Eastern Europe and how is Bucharest related in this case ? Second, What is the evolution of the labour force during the transition period from the socialist planned economy to the market economy? and third, What are the trends in localization of the new industrial sites? The first question is addressed using authors compiled data from the Colliers International Reports (2005, 2007) scientific literature and observation sheet applied at the industrial sites in Bucharest. The second draws on the data providing by the Romanian National Institute of Statistics and Economic Studies. The independent variables are derived from Geographic Information Systems (GIS) and the field observations. 
Putting together those data sets, the paper provides distinguish insights into the effects of postsocialist deindustrialization.

\section{Functionally changes in use of the former socialist plants in the Central and Eastern Europe}

After the fall of the socialist regimes in the late '80s the plants of CEE have experienced radical economic and political reforms. The transitions to market economy, liberalization of domestic markets, and integration into international economic system were the new challenges for the former socialist plants. One of the main questions that result for this if we can identify a common pattern of deindustrialization in postsocialist cities? In order to get an answer to this question we collected data about several cities of CEE based on secondary analysis of existing studies about main cities.

One of the first trajectory of the postsocialist plants was the fragmentation in smaller productions units. This tendency is explained by the production cut of the large enterprises that are forced to rent their buildings to small business. Other functionality changes are the the plant abandonment (predominantly before 2000s) and later demolition. The land of plant became a part of speculative and gated community real estate activities. The tendency is identified mostly in Moscow and largest cities of the former German Democratic Republic. Mostly of them with pollutions problems and their use for other activities is restricted by the terrain contamination. The recovery of this area was more easily to be supported in the case of those with the central position, nearby city centres, with their advantageous in terms of the accessibility and reconversion of industry with tertiary functions.

The main asset of postsocialist companies become the land, many time centrally located. The abandonment determined the transformation of the production sites in brownfields, available for reuse or non-industrial activities. In some cases, the legal status of industrial sites, particularly the largest plants, remains unresolved. In Łód , Poland, the industrial empty sites located close to the city centre attracted new housing, predominantly single-family detached houses and gated condominiums. These areas initially were dominated by disadvantaged people, but the improvement housing construction enthralled higher classes (Marci czak \& Sagan 2011). The most complicated problems remain the armaments industry and formerly research and technology complexes that cannot be privatised and their economic survival is threaten by underfunding (Rudolph \& Brade, 2005).

One of solutions to mitigate the challenging problems of brownfields was the settled scientific parks, usually close to the universities and research institutes. In Budapest, on seven hectare brownfields was developed the first scientific and technological park in CCE, named Informatikaiés Technológiai Innovációs Park (Infopark - Information and Technological Innovation Park) (Barta et al., 2006), primarily designated for the World Exhibition to be held in Budapest in 1996. The private investments were IT based (IBM, Hewlett-Packard, Magyar Telekom, Panasonic, Maxell, etc.). Another example of Budapest is Graphisoft, also occupied predominantly by IT companies. From this examples result that 
the brownfields redevelopment has been controlled by market forces rather than local government initiatives (Stanilov, 2007).

Other postsocialist plants made the transition from the production to retail and office buildings function. The typical new functions in the former plants and brownfields sites are shopping centres, office buildings or technological parks. The geographical position plays also an important role, thus with peripheral position has not modernised, the former building with little interventions been used for commerce, warehousing and logistic activities. Some example suggested that more profitable is construction of office buildings than houses, such is Dorottyaundvar [Dorottya Courtyard] in Budapest a conversion of industrial buildings (Barta et al., 2006). First commercial centre with regional function was opened in 1996 in Budapest. The Duna Plaza and Árkád shopping centres, Mamut shopping and entertainment centre, Millenáris Park, MOM Park, were erected on a former industrial area, whilst the Pólus Centre was built on area of a former military barrack.

After the fall of production in the former socialist plants, industrial activities were transferred to the new suburban zones, mostly of them on greenfield sites, with no pollution or other uses. Primary suburban developments were shopping malls, quickly followed by the erection of industrial plants. Preferred were the suburban area with existing infrastructure, principally the motorway, trunk roads and airports, and the second condition was the connections of this transport infrastructure with the global interfaces (international airports). The main effect was the deteritorialization of production, and in the future is expected the development of vibrant centres and expansion zones in the suburban area (Rudolph \& Brade, 2005; Sýkora, 1999).

The quick access to the city and the local fiscal facilities are main reasons that support relocation of industry at the periphery. The food processing industry and vegetable wholesaling or high-turnover retail facilities accompany residential suburbanization and were the first investments out the inner city. These can represent a basis for the development of dynamic new centres and growth zones in the periphery. Greenfields site also were attractive for retailers with large area required, such as Metro, Ikea, Hornbach, automobile retailers, gas stations (Staddon \& Mollov, 2000). This case, the new suburban region landscape appears as a mixed use industrial, commercial, office and residential. It can be interpreted as a convergence with the growth of Western urban regions (Rudolph \& Brade, 2005). The process is well-known in Western literature been named 'urban sprawl' with associated problems as increasing automobile traffic, air pollution, increasing public cost for providing infrastructure and services etc. Moreover, it has been registered a disconnection between residents and residential services (Stanilov, 2007).

The most advanced use of former postsocialist plants in terms of preserving and restoring the buildings is the transformation of ex-industrial sites for consumption and cultural purposes. The main predisposition for the brownfields or abandoned manufacturing activities was to demolish the former industrial plants and only in few cases the important thing was their conservation as the architectural monuments. Barta el al. (2006) argued that keeping the original function is not feasible, with some exceptions (breweries, infrastructure systems). The authors' assertion is to preserve the plants by identified new 
function, although these are complicated to find. They offer some positive examples such is Millenáris Park built on the premises of Ganz Villamossági Movek (Ganz Electric works) on the Buda side as a comprehensive industrial rehabilitation project.

Cultural use of the industrial buildings started in the middle of '90s. In the case of Budapest, the ports by the river Danube and the halls of the shipyards were the firsts industrial facilities used for cultural activities, such as organise folk, ethno and world music concerts, in the so called Fonó Budai Zeneház (Spinnery Buda Music House). In the 1998, the Trafó a former transformer station is one of the most famous alternative cultural centres of Budapest. The centre reconstruction was financed by the Metropolitan Municipality and also it offers financial support for the operation. Barta el al. (2006) state that non-profit community initiative failed due to the lack of funding. After 2000, the private investors were attracted into the conversion of industrial building for cultural purposes. In Budapest the private museum called MEO opened in 2001 on the premises of a former leather factory.

\section{Data and methodology}

\section{Study area}

Bucharest, the capital city of Romania, is the case study for the analysing the deindustrialization effects in the CEE. The city was strongly industrialised during socialist period. It is the largest Romanian city $(2,106,144$ inhabitants and $237.87 \mathrm{~km} 2$ area) and densely populated $(8,849$ inhabitants per $\mathrm{km} 2)$. It is predominantly compact, with a mix of old administrative and residential buildings in the city centre, surrounded by the prefabricated housing from the 1970 s to 1980 s, after the state intervention in spatial city reconfigurations. Socialist industrialization transformed Bucharest in the main industrial centre of the country. In this condition the city registered a continuous population increase, been advantaged by country capital status, with political, administrative and cultural functions. It is pour in natural resources, the single resources were represented by sands and argyles, the raw material used for construction at the end of 19 th century.

In the Bucharest's industrialization history were dominated several political and economical processes that determined the increasing industrial plants number and industry share in the economy. Industrialization was firstly related with the army factories built-up at the end of 19th century. The military plants had different profile (guns, textiles, or food). Until the 1950s almost entire western area was used by the army. The present city ring road is related with the former military forts, and it plays an important role in today factories relocation.

During socialist period, mostly of the military plants were converted for civil use and large area were received residential use. During the inter-war time private investments were oriented for the new industrial plants built-up for metallurgy and equipment's machines, petrol extraction, chemical industry, electric energy and cars or trams. After WWII, Romania became a part of communist bloc, and its economic system was disconnected from the market 
oriented policies. The state decided which are the industrial activities sustained. The industry development was based on the modernization of the former private factories. In some cases, especially in the textile industry, state decide to join the small factories in a few industrial plants. In 1965s, in the city were six large textile plants (three for cotton, one for flax and hemp, one for wool and one for natural silk). This industrial pattern, with more than 3,000 employers per one plant, was not exclusively for Bucharest. At the national level, this type of plant represented $16.2 \%$ of the total industrial plants number and counted $59.8 \%$ of total industry employers (Popescu, 2000). As in other cities, in Bucharest were established industrial plants that attracted external migrant, and the villages surrounding became part of the city due to the built-up of socialist prefabricated housing blocks.

In the early 1970s economic policies promote a new type of industry in Bucharest, named the 'new economy', in which were integrated heavy industry with new branch, such as electronics, automatic, IT, petro-chemistry and synthetic fibres and yarns. In the late 1980s in Bucharest were nine industrial areas which integrate new and old plants, entirely state controlled.

\section{Data sources}

In order to understand the tendencies and transformation of urban space in the last twenty years, we made an analysis of urban land use, the city economic structure and use of industrial plants before and after socialist period. This approach allows us to evaluate the occurrence of deindustrialization and its main characteristics.

\section{GIS data}

One of the problems for the study fieldwork was the missing of an accurate and completely city map with the spatial distribution of the socialist plants. This map was necessary in order to compare the past situation with this of the present. Moreover, due to political restrictions, industrial plants were not mapped on the public city map during socialist time. In order to analyse the spatial arrangement of the plants, five maps dating from 1923, 1928, 1943, 1970 and 2005 were transferred in a Geographic Information System (GIS) software. Thus were georeferenced at the same coordinate system projection using as the basemap the military topographic map from the early 1970s. Using these maps and archival data was made a list of about two hundred socialist factories. During field-work we added other industrial plants which were not included in the mentioned sources. Further, were digitised the industrial buildings in a radius of $15 \mathrm{~km}$ from the city centre. These building were manually digitized using QGIS and Google Earth images.

\section{Site survey}

Next step after the plants localization on the map was to collect empirical data about each site. The fieldwork was conducted in 2008 and updated in 2016 by using high resolution images from Google Earth. The industrial site characteris- 
tics survey included questions about industrial plant name in before and after 1990s, location, main activities before 1990s, present status (i.e. it keep the activities as before 1990, activities change, abandoned, demolished partially or completely, rented space), does the plants has other subsidiaries and if Yes were are located, architectural value of the buildings, number of buildings inside the site, materials used for building it (brick, concrete or metal), who are the owners (Romanian company, foreign investors).

During the fieldwork we were unable to collect information about several sites, because some of the top managers were unwilling with such as studies and refused to answer our questions. Despite of these rejections, response rate was very high and the results are large representative for our study. The interviews allow us to bring together supplementary information about industrial plants, which were not included in the site observation sheet, and other data source (photos, archival documents, books and monographs, information about proximity industrial plants our former employers).

\section{Secondary statistical data}

Romanian Institute of Statistics provide a wider number of statistical data about the industry and labour market. For our study we asked for data about detailed structure of labour force (1992, 2002 and 2013).

\section{Results}

\section{Deindustrialization impact on the labour market}

Analysis of the labour market for 1992, 2002 and 2013 indicate that the employees number in the manufacturing sector decrease at almost quarter (Table 1). In 1992, in Bucharest, were 378,931 employees in industry, which represent $42 \%$ of the entire employees. In 2013 the number of industrial employees was 110,400 (10.12\% of total employees). Compared with the national situation, the industrial declining of Bucharest is more accentuate. In the same period analysed, in Bucharest, the share of the services sector increase spectacular at about $70 \%$ share of entire labour force. The most important rising was registered in commercial sector (from $7 \%$ to $19 \%$ ) and financial sector (from below $1 \%$ to $6 \%$ ).

\section{Recent trends in postsocialist plants using}

A synthetically map of the recent trends - same activity profile, mixed use, demolished - of postsocialist plants in Bucharest is shown in the Figure 1. Predominantly are industrial sites with mixed use, ranging from the same activities profile in a limited area/building of the former plants, renting buildings, commerce, services or abandoned. The postsocialist plants with the same activity profile are represented by food processing plants, transport and storage. If we take account that transport companies have local position, we can conclude that are still active those small plants which manufactured goods for 
Table 1. Occupied population by activities of national economy

\begin{tabular}{|c|c|c|c|c|c|c|}
\hline & 1992 & $\%$ & 2002 & $\%$ & 2013 & $\%$ \\
\hline Agriculture, forestry and fishing & 9,171 & 1.02 & 5,178 & 0.68 & 2,900 & 0.27 \\
\hline Mining and quarrying & 2,495 & 0.28 & 1,927 & 0.25 & 4,100 & 0.38 \\
\hline Manufacturing & 378,931 & 42.17 & 165,705 & 21.64 & 110,400 & 10.12 \\
\hline $\begin{array}{l}\text { Electricity, gas, steam and air } \\
\text { conditioning production and } \\
\text { supply }\end{array}$ & 14,804 & 1.65 & 20,275 & 2.65 & 10,200 & 0.93 \\
\hline Construction & 67,827 & 7.55 & 52,764 & 6.89 & 141,700 & 12.99 \\
\hline $\begin{array}{l}\text { Wholesale and retail; repair of } \\
\text { motor vehicles and motorcycles }\end{array}$ & 65,485 & 7.29 & 128,439 & 16.78 & 210,300 & 19.28 \\
\hline Hotels and restaurants & 21,197 & 2.36 & 17,327 & 2.26 & 29,200 & 2.68 \\
\hline Transport and storage & 67,036 & 7.46 & 69,349 & 9.06 & 60,700 & 5.56 \\
\hline $\begin{array}{l}\text { Information and } \\
\text { communication }\end{array}$ & 90,644 & 10.09 & 76,449 & 9.99 & 71,800 & 6.58 \\
\hline $\begin{array}{l}\text { Financial intermediation and } \\
\text { insurance }\end{array}$ & * & * & * & * & 67,800 & 6.21 \\
\hline Real estate activities & 8,330 & 0.93 & 20,131 & 2.63 & 7,300 & 0.67 \\
\hline $\begin{array}{l}\text { Public administration and } \\
\text { defense; social insurance of } \\
\text { public sector }\end{array}$ & 53,055 & 5.90 & 78,942 & 10.31 & 37,800 & 3.46 \\
\hline Education & 38,591 & 4.29 & 40,570 & 5.30 & 46,800 & 4.29 \\
\hline Health and social assistance & 43,034 & 4.79 & 48,872 & 6.38 & 56,400 & 5.17 \\
\hline Other activities & 38,068 & 4.24 & 39,678 & 5.18 & 233,600 & 21.41 \\
\hline TOTAL & 898,668 & 100 & 765,606 & 100 & $1,091,000$ & 100 \\
\hline
\end{tabular}

Source: National Institute of Statistics

* No data

the limited market of Bucharest. Keeping the activities in these plants is due to renting spaces to other companies. The representative case of the postsocialist plants renting are the textile and heavy industry.

The functional distributions of the firms renting spaces of the postsocialist plants reveals that these undertake non-industrial activities, without a dominance of one sector. It can be identified commerce and storages activities, advertising, textile, and transport services. The rest is very fragmented, with printing services, auto-services and IT companies, engine production, medical and electric equipment, constructions, chemicals, furniture, hotels and cultural activities. Moreover, it is a correlation between lohn production system (subcontracting of textile manufacture) and relative higher number of small factories in this branch.

The opposite type is abandoned plants, demolished or preservation, mainly largest plants which were connected with the national and international markets. Went bankrupt or awaiting the start of real estate project these plants are vacant. Some of them are olds, with historical and architectural values. For some of the were identified reconversion solutions but for others the status is uncertain.

In the case of long time abandoned, such as industrial areas of the former railways or the periphery plants, the emerging landscape is different than the urban. Since the decisions of abandoned the industrial profile the plants fall in a 


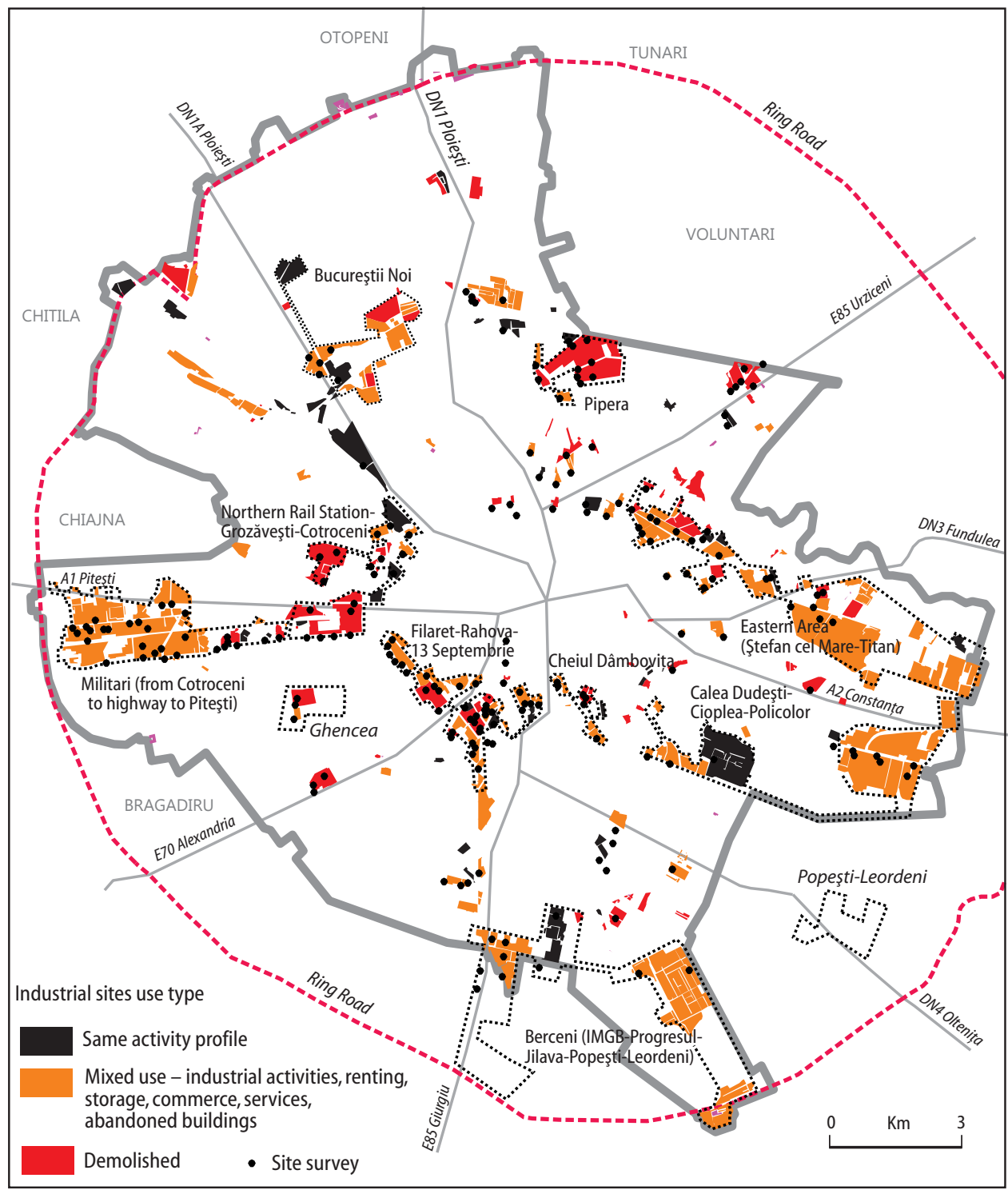

Figure 1. Present use of postsocialist industrial buildings

robbing process, initialized by workers, managers or people living around. Former buildings become desirably for marginal groups involved in gathering of equipment, pipes, bricks, metals or wood. (Chelcea, 2008). Another uses of the abandoned plants are "homes" for homeless people, ecological reserves, populated by plants resistant to spoiled, wasted soils, playground for children from the respective neighbourhoods or 'urban exploration', tourism.

The most frequently changing specialization field of postsocialist plants is the real estate. Confronting with the diminishing of activities and having a surplus of spaces, many factories have been transformed in real estate agents or real estate business. A limited number plants were transformed in business parks, spread on the large areas (40 hectares in the case of Sema Park). Due to the 
investments in the constructions sector, the land prices in the city centre or in the periphery increased enormous, mainly after 2001 (Grigorescu et al., 2012). In this context, the plants were most valuable as land - with good transport accessibility - rather than the industrial production. The former socialist plants were purchased by investors and speculators that demolished them and constructed in site other buildings. The field interviews with the real estate agents suggested a temporal relation between plants privatisation, demolish, and builtup on the former industrial sites. Moreover, the stage as industrial park is only a phase in the process of profitable capitalization of the land.

\section{Ring road industrialization}

In the context of inner city deindustrialization, the industries tend to be relocated on the Bucharest ring road. The new plants are located predominantly on the main roads linking the city: highways A1 and A2, national roads DN2 and DN3 and European road E70 (Figure 2). Valuable information about the actors and suburban industry dynamic were obtained from the reports of real estate company Colliers International Romania, field mapping and Google Earth satellite images. These evidence suggested that postsocialist industrialization is different in landscape and spatial distribution compared thus of communist time. Chelcea (2008) put them in relation with the "Big Box" western model, with metal warehouses, faster built-up and organized as Just-in-Time production system.

According to Colliers reports, the first warehouses were built-up in the northern municipalities, on the axis Bucharest-Ploiesti. The representative case is Otopeni town whose landscape was profoundly transformed in the last fifteen years with the construction of headquarter companies, warehouses and showrooms. The new buildings were not limited only to the ring-road. Due to the increasing land prices in the Bucharest economic boom of the 2001-2002 the investors moved to eastern area of ring-road, in the sector between Otopeni and national road (DN2) Bucharest-Urziceni. The industrial investments of 20042006 were located in ring-road sector between national road - DN2 and national road DN3. The traffic restrictions for trucks in the northern Bucharest area determined investors to locate their warehouses investments in the western part along the highway to Pitesti. In the same time the southern area, particularly the south-eastern became more attractive due its location nearby A1 highway to Constanta (Colliers International, 2005). The renting companies in warehouses are logistical firms (77\%), hypermarkets (9\%) consumer goods $(7 \%)$ and pharmaceutical (2\%). (Colliers International Reports, 2007: 43).

\section{Discussions}

Bucharest City still has 110,400 employees in industry, but the tendencies suggest that it can be included in the category of deindustrializing cities. Losing jobs in industry represent a general involution of manufacturing sector. In the national context it is not a singular case. There were some single industry towns as Copsa Mica or Jilava where the closing of the main plant determined unem- 


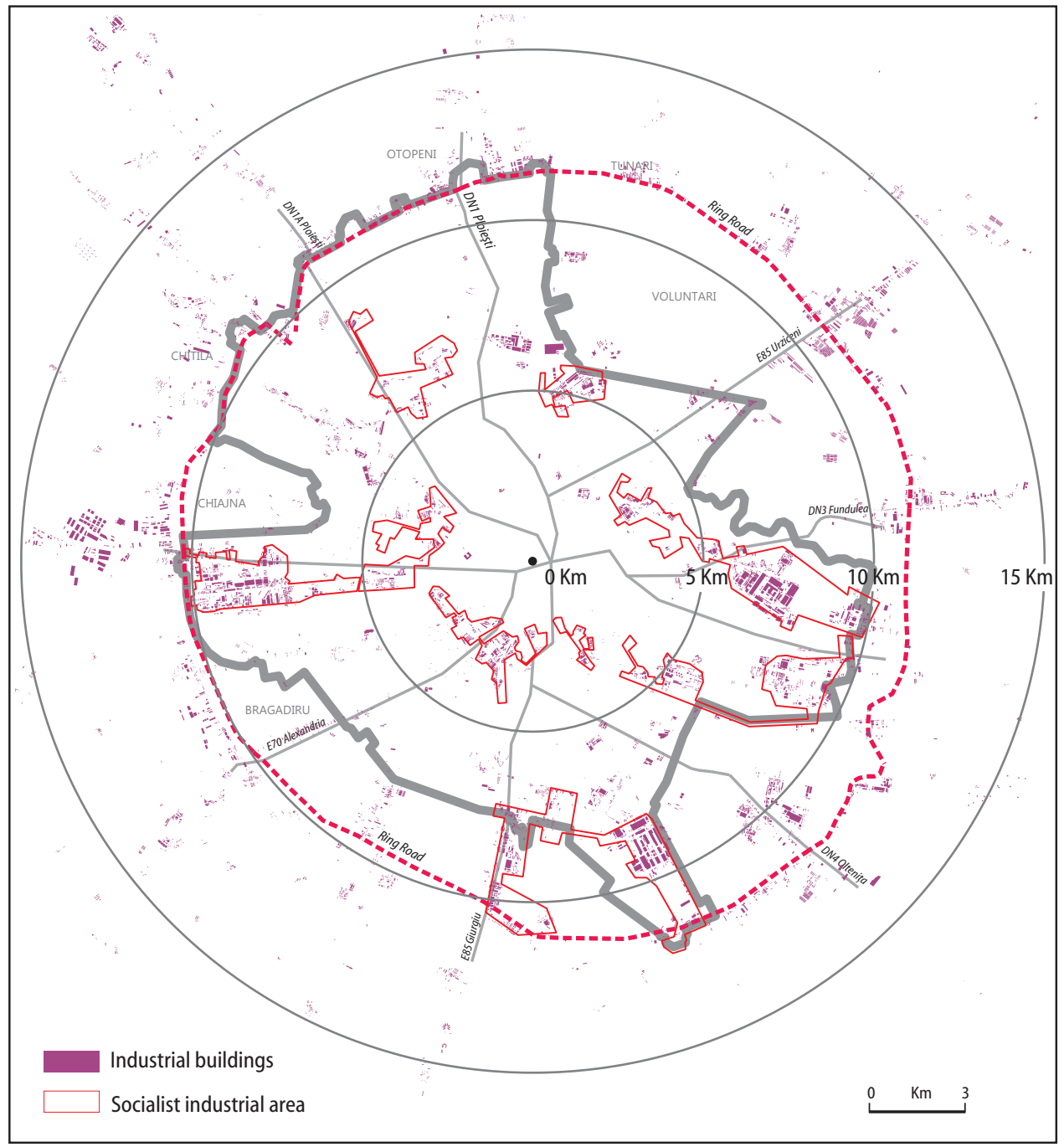

Figure 2. Industrial buildings in Bucharest metropolitan region

ployment and people migration domestic or abroad the country. From the statistical data we can make the assertion than economy of Bucharest is the service based. Moreover, a strategy study elaborated by the Bucharest-Ilfov county Regional Development agencies state that service sector represents $67.9 \%$ of occupied population and industry account 22.6\% (ADRBI, 2005). The percentage of the firms which belongs to services is $60-61 \%$ of the industrial spaces.

Postsocialist privatisation of the former plants create new opportunities and risks for the management of these plants. Some of them registered a diminishing of production and others shut down the production. The reasons were disparate. In several cases it was the competition of the cheaper product from import, as in the case of the Matches Factory which could not resist due to imports from the former soviet states. The air quality control caused the switch of others plants because of the air pollution as was the case of the slaughter- 
house and the concrete factory. Other plants sufferers of monopolistic pressure after privatisation. In this case we included an oil plant that was closed by the owners after they bought others two plants with the same profile in Oradea and Iasi. Old technologies determined the bankrupt of several plants. The tendency is to increase the number of demolished plants. These are replaced by house blocks, hypermarkets and shopping malls. Chelcea and Simion (2007) identified that some of the demolished plants had architectural and historical values, without a strategy from the owners and local government to protect them from use conversion and demolish.

Decreasing of the activities was not registered only quantitative but also from the point of space using by the plants, especially in those who changed the old technology from socialist or pre-socialist time. Since the purchasing of modern equipment the size of these are small and a large plant area became available. The phenomenon is accentuated by the fact that during socialist time were necessarily storage spaces for raw materials. The current techniques of packing and delivery providers have removed this pressure on factory space.

The transformation of the existing plants until 1989 from independent business to real estate agent which rent spaces to other firms generate the phenomenon of "factories in factories" (Chelcea, 2008). This conversion was in the majority cases spontaneous, determined by request form the small firms. The plants owners made important efforts to flexibly the space and to rent it to other companies. Those arrangements were made with fewer investments by the plants owners or by those who rents. Other buildings are renovated when the receipts from renters become more consistent. Some of them end up almost entirely losing their architectural authenticity. In the vision of the real estate investors, former socialist plants of Bucharest represent the best opportunities. In their views, the place and buildings plants are lost for any cultural, affective and historical values. Unfortunately, the same perspective on the old plants is encouraged by the local authorities. The tendencies of demolition and erase of the memories is away from the preoccupation of City Hall and investors.

Analysing the specialization of the plants before 1989 we cannot affirm that several sectors were most affected. Diminishing of production and renting influenced relatively uniform all the activity domains. Site surveys sustains the studies about transition that identified commercial activities and exchange as predominantly comparative with the production (Burawoy \& Verdery, 1998; Duží \& Jakubínský 2013).

Bigger cities as Bucharest has a great spatial influence in the economy and labour market in the suburban areas, even are services or the work commuting of the population. One of the visible landscape evolution is that industrial buildings are relocated in the suburban area and the changing labour market structure in the city region. The trend of (re)location of the plants to the suburban area will continue. There are indications that beginnings of the suburban industrial activities resume the evolution registered in the western countries. The tendency of suburbanization follows those of split in the industrial zones specifically for socialist period. The best example results from the spatial distribution of industry in the ring road. The construction of new highway Bucharest to Brasov will be a new line for a faster relocation of industrial activities from city urban core. 


\section{Conclusion}

This paper illustrates that deindustrialization in the Central and Eastern Europe show important transformation after de collapse of socialist system. Socioeconomic structure made a significant move away from industry to service sector in a period of 25 years. The present use of former plants demonstrates a common pattern trend, characterised by the conversion and demolition and only in several cases the preserving of industrial activities. Changes in the use of postsocialist plants are related with the land values, most of them been located in the inner city core or in the proximity of the city centre. In this condition, the plants became real estate agents which rent or sell the industrial buildings or land. This is a growing tendency as an influence of market principles of selling or renting the most valuable land and closing or relocation in the suburban area of the former industrial activities. It would be interesting an increase of the studies on deindustrialization in CEE, as still are a limited number of papers on this topic. There it will be interesting the compare the socio-economic transformation of postsocialist economy with the situation of Western Europe that experienced an early capitalist deindustrialization.

\section{References}

Barta, G, Beluszky, P, Czirfusz, M, Gyiri, R \& Kukely G 2006, Rehabilitating the brownfield zones of Budapest, Centre for Regional Studies of Hungarian Academy of Sciences - Discussion Papers, Pecs.

Chelcea, L 2008, Bucureştiul Postindustrial. Memorie, dezindustrializare şi regenerare urbana, Editura Polirom, Iasi.

Chelcea, L \& Simion, G 2007, Dezindustrializarea, resemnificare şi reconversie urbana, in: Kombinat - Ruine ale Epocii de Aur, Igloo, Bucureşti.

Colliers International (2005), Central and East Europe, Mid-Year Real Estate Review.

Colliers International (2007), Real East Review, Romania.

Czepczynsk, M 2012, Old Industrial regions (I) - Gdansk, Poland. De-vs. Re-Industrialisation Of Post-Socialist City. The Case of Gdansk, www.staff.ncl.ac.uk/p.s.benneworth/oirs/czepczynski.pdf, last accessed: January 29, 2012.

Duží, B \& Jakubínský J 2013, Brownfield dilemmas in the transformation of postcommunist cities: a case study of Ostrava, Czech Republic, Human Geographies, vol. 7, issue 2, pp. 53-64.

Grabher, G 1997, 'Adaptation at the cost of adaptability? Restructuring the Eastern German regional economy', in Grabher, G \& Stark, D (eds.), Restructuring Networks in Post-socialism. Legacies, Linkages and Localities, Oxford University Press, Oxford, pp. 107-34.

Grigorescu, I, Mitrica, B, Kucsicsa, G, Popovici, EA, Dumitraşcu, M \& Roxana Cuculici, 2012, Post-communist land use changes related to urban sprawl in the Romanian metropolitan areas, Human Geographies, vol. 6, issue 1, pp. 35-46.

Hirt, S 2008, 'Landscapes of Postmodernity: Changes in the built fabric of Belgrade and Sofia since the end of Socialism', Urban Geography, vol. 29, no. 8, pp. 785-810.

Illne, M \& Andrle, A 2012, The regional aspect of post-communist transformation in the Czech Republic,

http://sreview.soc.cas.cz/uploads/1296edeab13bd23b20c3e9febaae6f165c9590aa_492_107I LLAN.pdf, last accessed: January 29, 2012. 
Kiss, E 2007, 'The evolution of industrial areas in Budapest after 1989', in Kiril Stanilov (edit), The Post-Socialist City Urban Form and Space Transformations in Central and Eastern Europe after Socialism, Springer, Dordrecht, The Netherlands.

Kotus, J 2006, 'Changes in the spatial structure of a large Polish city - The case of Poznan', Cities, vol. 23, no. 5, pp. 364-81.

Lentz, S 2002, 'Moskau - aktuelle Stadtentwicklungsprozesse', Geographische Rundschau, vol. 136, no. 4, pp. 29-33.

Lichtenberger, E 1994, 'Vienna and Prague: political systems and urban development in the postwar period', in Barlow, M, Dostal, P \& Hampl M (eds.), Development and Administration of Prague. Universität Amsterdam, Amsterdam, pp. 91-115.

Lintz, G, Müller, B \& Schmude, K 2007, 'The future of industrial cities and regions in central and eastern Europe', Geoforum, vol. 38, pp. 512-19.

Marcińczak, S \& Sagan, I 2011, 'The socio-spatial restructuring of Łódź, Poland', Urban Studies, vol. 48, no. 9, pp. 1789-1809.

Noody, A 2012, Socio-Economic segregation and urban form in post-socialist Budapest, www.fulbright.hu/book4/anthonynoody.pdf, last accessed: January 29, 2012.

Nuissl, H \& Rink, D 2005, 'The 'production' of urban sprawl in eastern Germany as a phenomenon of post-socialist transformation', Cities, vol. 22, no. 2, pp. 123-34.

Polanska, D. 2008, 'Decline and revitalization in post-communist urban context: A case of the Polish city - Gdansk', Communist and Post-Communist Studies, vol. 41, pp. 359-74.

Rudolph, R \& Brade, I 2005, 'Moscow: Processes of restructuring in the post-Soviet metropolitan periphery', Cities, vol. 22, no. 2, pp. 135-50.

Staddon, C \& Mollov, B 2000, 'City profile - Sofia, Bulgaria', Cities, vol. 17, no. 5, pp. 379-87.

Stanilov, K 2007, 'The restructuring of non-residential uses in the post-socialist metropolis', in Stanilov, K (edit.), The Post-Socialist City Urban Form and Space Transformations in Central and Eastern Europe after Socialism, Springer, Dordrecht, The Netherlands.

Sýkora, L 1999, 'Changes in the internal spatial structure of post-communist Prague', GeoJournal, vol. 49, pp. 79-89. 